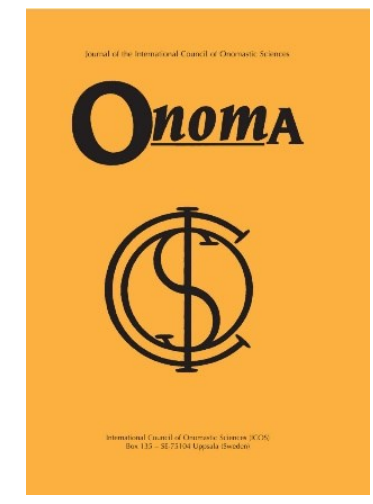

Onoma 54

Journal of the International Council of Onomastic

Sciences

ISSN: 0078-463X; e-ISSN: 1783-1644

Journal homepage: https://onomajournal.org/

\title{
The role of pragmatonyms in the formation of a post-apocalyptic worldview in a role-playing video game
}

DOI: 10.34158/ONOMA.54/2019/7

\section{Oleksandra Kuzmenko}

Pushkin Leningrad State University

36 Kuznechnaya Street, Apartment 3

65020, Odessa

Ukraine

oleksandra.m.kuzmenko@gmail.com

To cite this article: Kuzmenko, Oleksandra. 2019. The role of pragmatonyms in the formation of a post-apocalyptic worldview in a role-playing video game. Onoma 54, 117-135. DOI: 10.34158/ONOMA.54/2019/7

To link to this article: https://doi.org/10.34158/ONOMA.54/2019/7

\section{(C) Onoma and the author.}

The role of pragmatonyms in the formation of a post-apocalyptic worldview in a role-playing video game

Abstract: This research deals with the studying of Fallout game series pragmatonyms (product names) in terms of linguistic worldview formation as a result of a player-computer interaction. The computer game is considered as a media text as a fragment of a media discourse and a piece of fiction of a definite genre. Being a reality model, the computer game comprises a number of objects. In terms of expression, game objects are audio-visual parts of reality model responding to players' actions in a way similar to interpersonal communication. According to the content, they are the linguistic means of impact producing through semantically motivated names. Thus, the research question is the ways pragmatonyms take part in the formation of game worldview and creating player-game interactivity. For this reason, 424 pragmatonyms have been collected and analysed to prove that 
pragmatonyms are created according to the genre features and conforming to the interactivity of the game. Overall, pragmatonyms are the linguistic means of impact producing, regarding interactivity of the game and its genre features, and, consequently, take part in worldview modelling.

Keywords: Media text, game, pragmatonym, product name, interactivity.

Le rôle des pragmatonymes dans la formation de l'image du monde du jeu de rôle (la science-fiction postapocalyptique)

Résumé : Cette étude est consacrée aux pragmatonymes de la série de jeux Fallout du point de vue la formation d'une image linguistique du monde à cause de l'interaction entre le joueur et l'ordinateur. Un jeu d'ordinateur est considéré comme un texte multimédia, comme un fragment d'un discours multimédia et comme une œuvre d'art d'un certain genre. Un jeu d'ordinateur, qui est un modèle de la réalité, n'est rien d'autre qu'une multitude d'objets. Du point de vue de l'expression, les objets de jeu sont les parties audiovisuelles du modèle de réalité qui répondent aux actions des joueurs de manière anthropomorphique, proche de la communication interpersonnelle. Selon le contenu, ce sont des moyens linguistiques d'influence à travers des noms à motivation sémantique. Ainsi, la question de la recherche est de savoir comment les pragmatonymes participent à l'établissement d'une vision du monde du jeu et à son interactivité. Pour cette raison, 424 pragmatonymes ont été rassemblés et analysés pour prouver que les pragmatonymes sont créés conformément aux caractéristiques du genre et à la correspondance de l'interactivité du jeu.

Mots-clés : Texte média, jeu, pragmatonyme, nom du produit.

\section{Die Rolle von Pragmatonymen bei der Vorstellung des postapokalyptischen Weltbildes des RPG Spieles}

Zusammenfassung: Diese Forschung befasst sich mit der Pragmatonyme in der Fallout-Spieleserie, die sich mit der Vorstellung des sprachlichen Weltbildes als Ergebnis einer Spieler-Computer-Interaktion befassen. Das Computerspiel wird als Medientext als Fragment eines Mediendiskurses und als Fiktion eines bestimmten Genres betrachtet. Das Computerspiel als Realitätskonstrukt ist nichts anderes als eine Reihe von Objekten. In Bezug auf den Ausdruck sind Spielobjekte audiovisuelle Teile des Realitätskonstrukts, die auf die Handlungen der Spieler anthropomorphische Reaktion haben, und der zwischenmenschlichen Kommunikation nahe sind. Sie sind sprachliches Mittel, um durch semantisch motivierte Namen Wirkung zu erzeugen. Die Forschungsfrage ist daher, wie Pragmatonyme an der Festlegung des Spielweltbildes und der Gewährleistung der Interaktivität zwischen Spielern beteiligt sind. Aus diesem Grund wurden 424 Pragmatonyme gesammelt und analysiert, um zu beweisen, dass Pragmatonyme in Übereinstimmung mit den Genremerkmalen und der Interaktivität erfunden sind. Insgesamt sind Pragmatonyme die sprachlichen Mittel, die Auswirkungen auf die Interaktivität des Spiels und seiner Genre-Merkmale haben, und nehmen folglich an der Modellierung des Weltbildes teil.

Schlüsselbegriffe: Medientext, Spiel, Pragmatonym, Produktname, Interaktivität. 


\title{
The role of pragmatonyms in the formation of a post- apocalyptic worldview in a role-playing video game
}

\author{
OLEKSANDRA KUZMENKO
}

\section{Introduction}

It is now generally accepted that computer games play a major role in our lives. In the digital age, computer games have been recognized as a form of art (Protalinski 2011) that incorporates both visuals and technology. Computer games have critically influenced the modern cinematography, giving rise to the making of films based on games, and education field, resulting in a tendency to gamify the learning process. However, much is yet to be done in terms of studying the player-game interaction from a linguistic perspective.

A video game or a computer game dates back to the creating of the first electronic computing machine in 1946. Primarily ENIAC (Electronic Numerical Integrator and Calculation) was designed for ballistics purposes. However, it appeared to be capable of solving problems in many spheres (Kazakova 2011: 87; hereinafter, Russian-language reference materials are translated by me). Starting from the 1970s and up to the present times, the computer games have been evolving with rapid developments in technology and turned into the form of drama. Rollings \& Morris (2006: 39) emphasize that all the rules of drama are applied to any game, and the key elements of drama are the plot, the theme, the genre to which the story belongs, the characters, the setting, and the audience.

In this research, a computer game is considered as a media text regarding the expression and a piece of fiction of a definite genre regarding the content. As a media text, it has the following features: media character, mass nature (both in the spheres of creation and consumption of media products), integrity or polycode nature, and openness (Kuz'mina 2011: 13). As Rogers (2010: 41) notes, computer games are an interactive medium. Burlakov (2000) defines interactivity as an opportunity for the player to actively influence the game world. He points out the superiority of a computer game over cinema, theatre, and literature as means of diving into the fictional world with great freedom in choice making.

According to Galkin (2007: 67), the game world is an abstract entity that is restricted to a number of various objects and aims at the credibility to create an illusion of a real world. The onyms (proper names), being semantically motivated, are the linguistic means of producing impact on a player. Thus, such a player-objects correlation has an intermutual nature and is a result of 
interactivity of a game as a media text. This paper focuses on studying the role of such names in terms of game worldview formation.

The present study analyses pragmatonyms as names for "sort, brand, tradename identifying" (Podol'skaya 1978: 113). Concerning the importance of studying proper names in the game worldview formation, I believe that, first of all, it is based on the purposefulness of game objects' naming. Many scholars agree that common words are unmotivated, for example, a conventional symbol, according to Ferdinand de Saussure (1977: 99), is free from any visible connection with the designated object. In poetic language, however, onyms are and must be motivated. By poetic language the poetic or aesthetic function of the language is meant, dating back to the Prague linguistic circle and works of Roman Jakobson and Jan Mukarrovský. It is implied that poetic language comprises a fictional text. In the article "Linguistics and poetics", Jakobson (1975) emphasizes its evaluative nature. Jakobson (1975) states that, in contrast to the conventional nature of the linguistic sign in linguistics, the poetic language is characterized by purposefulness, namely the motivation of the sign for the author to achieve a certain goal. Being connected to the author's worldview and the goals set by the author, the poetic or aesthetic function is designed to stir certain emotions in response to a specific message.

Studying the issue of drug vendors' usernames and the purposefulness of naming, Hämäläinen (2019b: 56) emphasizes that the names are used to identify the vendor, with consumers retracting essential information characterizing a definite vendor. The level names in games, as it has been studied by Hämäläinen (2019a) on the material of an online virtual minigolf game, are also created based on the important levels' elements and their interactive characteristics. The same is true for the game objects' names. They take part in preliminary identification of objects, adopting an appropriate strategy by players, and formation of a game worldview.

Consequently, a term linguistic worldview as a linguistic notion should be defined, as, in the case of this study, it is closely related to the game worldview. Referring to the linguistic worldview, I mean not only the inner world of a piece of fiction but also the link between the author of the work and the audience. The linguistic worldview of the author (writers, poets, computer game designers etc.) is defined as an individually and creatively verbalized representation of the world from the perspective of the author's consciousness. Moreover, the perception of the author's linguistic worldview by the audience is possible only after correlating it with the background knowledge of the addressee. The importance of background knowledge and understanding of the "meta-sense" of a work (something that has not been said but is the key to understanding a piece of art) is highlighted by linguists as well as game designers. It is possible to consider the term linguistic worldview within the framework of four approaches - cognitive, psycholinguistic, cross-linguistic, and traditional (Yakovlev 2017). From the point of view of the cognitive 
approach, the linguistic worldview is a system of conceptual representations of reality expressed through the linguistic form (Yakovlev 2017: 9). The importance of the cognitive approach in onomastics is emphasized by the specific nature of a proper name - by naming a particular object, a person not only consolidates information about it but also "converts this information into a plane of correlation with other entities that are important for the human perception of the world" (Shherbak 2012: 36). In other words, the names are not built in isolation but in conjunction with the names of other objects, and the naming process itself is characterized by a systematic nature.

Psmit (2006) emphasizes that the name must be consistent with the game worldview - a logical detail of a game world. Thus, in accordance with the genre, there are some restrictions in naming. Rogers (2010: 53) adds to the issue that it is not only important to title the game correctly but is also vital to give the characters the right names, considering their personality, occupation etc. A name should be functional, depictive, and foreshadowing. Rogers (2010: 53) provides a great example to illustrate the case: "What does the name Luke Skywalker tell you about the character? Luke feels like a simple, homespun name fitting for a farm boy who yearns to "walk among the stars"'. Martin (2011) also discusses the importance of appropriate naming to create a definite impression of a given location. Studying toponyms of the computer game Grand Theft Auto IV, he uses the term literary toponymy classifying game toponyms as means of textual strategy or literary devices (Martin 2011: 5). The same is true for pragmatonyms as they are part of game onomastic worldview.

Fallout, as the data source, is a series of post-apocalyptic role-playing video games (RPG). The choice for studying pragmatonyms to investigate the ways of producing the player-game impact stems from the major role of pragmatonyms in the RPG part of the game: the player's interaction with items (e.g. collecting the items in the inventory, enhancing the character with the acquired items, affecting the character in any way) as the exploration is one of the four main RPG elements (HiddenX 2014). Nearly all the consumables affect the player character in one or another way (e.g. improving the health or hit points, raising the radiation level etc.). Moreover, a number of them influence the S.P.E.C.I.A.L. system that is an acronym for Strength, Perception, Endurance, Charisma, Intelligence, Agility, and Luck, and poses a ruleset of the game.

For this study, 424 pragmatonyms have been selected from Fallout: New Vegas and Fallout 4, the fourth and fifth major instalment in the Fallout series released in 2010 and 2015. The names were not gathered from the game directly but from the entries in Nukapedia, a Fallout game guide based on the principles of Wikipedia. Having Nukapedia as the material source, the study aims at profound research of the names, their background and possible references.

The study investigates the ways pragmatonyms take part in the game worldview formation and the impact they produce on a player in terms of the game interactivity. Three main research questions are proposed: 
1) What is meant by a pragmatonym in Fallout and what are the wordbuilding patterns of pragmatonyms?

2) What is the function of onyms in game worldview formation regarding the game as a piece of fiction of a post-apocalyptic genre?

3) What is the role of pragmatonyms in the game worldview formation in terms of game interactivity referring to the game as a media text?

The first three questions are answered in three separate analysis sections (2.1-2.3), and the findings are given in the conclusions. Before addressing the research questions, related work should be shown, with emphasizing novelty and importance of current study.

\subsection{Related work}

This research deals with studying the Fallout onyms, regarding linguistic worldview formation as a result of a player-computer interaction. In recent years, researchers have become increasingly interested in the problem of interactivity: interactivity of new media, the player-game interactivity, audiovisuals, augmented reality etc. (Seraphine 2014; Goroshko 2015; Krasnoyarova 2015; Volkova 2017). However, few investigations have focused on onyms as means of studying the interaction creating with the investigation of the naming system. The issue is mainly addressed by engineers or game designers (Rollings \& Morris 2006; Rogers 2010; Spector 2013; Cooper \& Scacchi 2015; Shaker et al. 2016), gamers or video game journalists (Psmit 2006; HiddenX 2014), fiction writers (Bissell 2010), researchers in the sphere of digital game studies (Martin 2011), and onomasticians (Butler 2016; Kuzmenko 2018a, 2018b; Hämäläinen 2019a, 2019b).

The interest of onomasticians in studying the game onyms is based on the fact that the game comprises a number of objects, all of which have names, even if they are not visible to players and aimed at the facilitation of the game designing process. The objects' names are linguistic means of producing impact and developing worldview through their motivation.

In terms of the genre of Fallout game series, the post-apocalyptic genre has been studied as one of the most popular fiction genres (Ivanova 2013; Dydrov 2015; Berezovskaya \& Demchenkov 2016; Chesnova et al. 2017) with its specifics being separated from those of other closely-related ones. In my previous research (Kuzmenko 2018b), the expression of the acceptability category as one of the genre-forming features of the post-apocalyptic fiction was investigated on the material of the Fallout game series. It was noted that it occurs in the form of gradation and opposition.

This study expands the research of the role of pragmatonyms in game worldview formation (in newer Fallout games) in addition to the issue addressed in my previous study (Kuzmenko 2018a), where the role of pragmatonyms in the Fallout worldview formation was investigated on the material of Fallout 1, Fallout 2, Fallout 3 (87 onyms analysed). 


\subsection{Terminological question}

In Russian onomastics, the term onym is used instead of the internationally more usual term proper name (or shortly just name). It serves as an umbrella term for different groups of onyms such as anthroponyms, zoonyms, pragmatonyms, theonyms etc. (Podol'skaya 1978: 95). The principle of terms formation, given in the Dictionary of Russian Onomastic Terminology, seems to be worth mentioning. It is preferable that the basis of the term be predominantly of Greek or Latin origin. It ensures an international understanding of the term, avoiding unnecessary false associations. The example of the naming pattern would be topo-, anthro-, cosmo-, astro-, pseudo- + -onym, with the latter being capable of functioning independently. I believe that the application of term onym, as an umbrella term and as a part of a proper name (anthroponyms, pragmatonyms etc.) adds much to the study in terms of notions distinguishing.

The term pragmatonym is generally understood to mean the names for a sort and a brand of products. As stated in the List of Key Onomastic Terms (see ICOS in references), the term product name is used instead with a similar meaning. Thus, in the current study, the terms onym (proper name, proper noun) and pragmatonym (product name) are used. The latter is used to refer to all types of consumables in Fallout.

\subsection{Data and methods}

Fallout was chosen as the data source because it is one of the most popular and influential video game series. It is a post-apocalyptic computer role-playing game (RPG), developed and published by Interplay Entertainment, Black Isle Studios, Micro Forté, Bethesda Softworks and Obsidian Entertainment. This study focuses in two games in the series, Fallout 4 and Fallout: New Vegas. Fallout 4 (Bethesda Softworks 2015) is the fourth and latest game in the main series, while Fallout: New Vegas (Obsidian Entertainment 2010) is the first of four spin-offs of the original series.

Regarding Fallout game series worldview, the impact of the pragmatonyms is investigated in two directions - regarding the game as a postapocalyptic fiction, and with respect to the game as a media text. By worldview formation, we consider the image formation of two Americas - the one retrofuturistic (similar to the USA of the 1950s) and the other a post-war, postapocalyptic one. As noted by Berezovskaya \& Demchenkov (2016: 65), a postapocalyptic world modelling takes place in two layers: the description of the pre-apocalyptic living and non-living objects evolving and adapting to new conditions; and the development of a new post-apocalyptic world. The genreforming characteristics of a post-apocalyptic fiction are the implementation of oppositions, the demonstration of gradation category, the description of objects evolving and adapting. The pragmatonyms, as well as other objects' names, are hypothesized to correlate with these genre features. 
As a media text, a computer game has the following basic features: popularity, relevance, actuality, contextuality, intertextuality, stereotypy, standardization (Krasnoyarova 2010: 179-180). Maksimenko (2011: 52) states that the media text of the Internet meets all the traditional text features, but, in addition, it has one significant independent component - interactivity. Krasnoyarova (2015: 93) considers interactivity as an essential part of modern communication and a way of people existence in media reality.

Discussing the genre of Fallout, Bissell (2010: 4) defines it as the openworld or sandbox or free-roaming game, pointing out some genre specifics such as a large world as a model of reality, the main storyline with some sidelines, an ability to create a unique player character, and a number of non-player characters with whom the player can interact. Noting the surging interest in the open-world games, Butler (2016: 24) gives the Fallout series as an example of game series with a "more crafted form of open-world game", stressing the role of interactivity as means of forming the player's experience within the virtual world. The utmost necessity of interaction is noted by many game designers (e.g. Spector 2013, Shaker et al. 2016). Thus, it is hypothesized that the products must be named in a way that ensures the beneficial interaction of players and game objects.

The interactive world of Fallout has a vast number of objects to engage with and gives the possibility of creating of the player character and self-naming. This study of Fallout pragmatonyms is based on data collected from Nukapedia (see references), a Fallout-themed online database (a wiki). The choice for Nukapedia as a data source stems from the number of articles, the relevance, and the quality of articles. It has 33,837 articles ${ }^{1}$, being among the most extensive databases on video games and by far the most extensive database focusing on Fallout. It appears often first in search engines when searching for Fallout-related information, therefore being important for many users. It also uses accurate article references and a developed system of administrators and moderators, seven kinds of users that are responsible for fulfilling definite tasks.

In this paper, the investigation was conducted within the cognitive approach to focus on the interactive function of the language. 424 pragmatonyms were selected with the continuous sampling method of all names of consumables according to the entries of Nukapedia. The componential analysis was implemented to highlight naming motivation that is vital for identifying the naming principle and defining its correlation with the genre. The elements of morphological and derivational analyses were used for a more integrated approach to the study. To investigate the interrelation of reality, its representation, and its perception, the cognitive analysis was applied, based on the main function of word formation (nominative function) being cognitive. Thus, the central problem in this research is the understanding of the correlation between the role of proper names and mental processes.

The situation on 31 March 2020 (Nukapedia). 


\section{Analysis}

\subsection{What is meant by a pragmatonym in Fallout and what are the word- building patterns of pragmatonyms?}

As already stated, the term pragmatonym has been applied to a name for sort, brand, tradename identifying. However, in broad terms, the pragmatonyms in Fallout can be used to refer to any consumables' names. It is justified by the post-apocalyptic genre's characteristics, namely the implementation of pre-war-post-war opposition. In the framework of pre-war world modelling, Fallout pragmatonyms denote a certain pre-war brand or trademark. However, regarding the formation of a post-apocalyptic worldview, it is not possible to speak of enterprises, as the post-apocalyptic world is characterized by the decline of civilization. Therefore, the term pragmatonym refers to any products created for further consumption.

The decision to study Fallout: New Vegas and Fallout 4 pragmatonyms separated from those in Fallout, Fallout 2, and Fallout 3 is justified by the following. Firstly, they are relatively new (released in 2010 and 2015) games in the series, and the game world seems to be bigger and genuinely open. Secondly, new game world objects that can be activated have been implemented. They are Campfire, Electric hot plate, Cooking station, and Cooking stove. These objects are used to cook raw products and create a wide variety of consumables from ingredients found in the Wasteland ${ }^{2}$. Crafted products tend to be more valuable and have an additional effect. Consequently, the possibilities for player-game interaction have increased. Moreover, the role of pragmatonyms in the Fallout worldview formation on the material of the preceding games was investigated previously, with 87 onyms being studied (Kuzmenko 2018a).

In order to analyse the pragmatonyms, the morphological analysis has been used. The results show that the pragmatonyms are subdivided into three large groups: the pragmatonyms consisting of one word ( 82 onyms), the compound pragmatonyms consisting of two words (204 onyms), and the compound pragmatonyms consisting of three or more words (138 onyms). In an attempt to justify the predominance of compound pragmatonyms over one-word onyms, the componential analysis has been implemented. Research has shown that such naming pattern is justified by the interactivity feature of a computer game as a media text. In particular, the usage of additional meaning, e.g. product quality (Crunchy mutfruit, Fresh pear, Irradiated water), location (Cave fungus, X-111 compound), or animal from which the product is made (Bighorner meat, Cazador egg), result in the compound naming patterns. The word meanings serving as bases of products' naming are studied in greater detail in part 2.3. of this study.

2 The Wasteland or Wastes refers to the majority of the world's post-nuclear environment in the Fallout universe (Nukapedia). 
In aiming at a full-scale investigation of naming patterns for possible application of obtained results, the word-formation of semantically motivated oneword pragmatonyms (65 units) was studied with the derivational analysis. Table 1 presents the most common word-building patterns of one-word pragmatonyms with a number of units that fall into the category shown and examples given in brackets.

Table 1: Word-building patterns of one-word pragmatonyms

\begin{tabular}{|l|c|l|}
\hline Word-building pattern & Count & Examples \\
\hline composition (compound words) & 31 & Buffout, Psychotats \\
\hline $\begin{array}{l}\text { lexical-semantic word-building } \\
\text { (transfer of meaning) }\end{array}$ & 15 & Overdrive, Tremble \\
\hline stem composition & 11 & Cateye, Razorgrain \\
\hline affixation & 5 & Addictol, Calmex \\
\hline abbreviation & 3 & Tato, the MRE \\
\hline
\end{tabular}

It seems vital to study the word-building patterns of onyms as it might be of great help for creating a naming guide for game designers to build names according to a given genre and given objectives, with the naming patterns shown.

Therefore, the Fallout pragmatonyms (one-word, two words, three or more words) are the names of any consumable relating to the pre-war or postwar world. The ways these names take part in the game worldview formation are further considered in parts 2.2. and 2.3.

\subsection{What is the function of onyms in game worldview formation regarding the game as a piece of fiction of a post-apocalyptic genre?}

Fallout is a piece of fiction from the point of view of its content. It tells the story of a post-apocalyptic, post-war world. One of the most common worldviews of ecological science fiction is a nuclear catastrophe and its consequences, the post-nuclear disaster worldview with people living deep underground or becoming mutants or through other means adapting. The most typical post-apocalyptic scenario is a destructed civilization after World War III with the use of the nuclear weapon while the civilization used to be technologically and culturally advanced prior to the incident (Ivanova 2013: 146-147). The scene, terra dystopia, is a scorched wasteland after a breakdown, with foreign organisms originating and evolving (Dydrov 2015: 110). It is important to note that the foreign organisms are vastly presented by already existing creatures like animals and plants changing under new conditions.

A post-apocalyptic world modelling takes place in two layers, the description of the pre-apocalyptic living and non-living objects evolving and adapting to new conditions, and the development of a new post-apocalyptic world. World-modelling is characterized by a gradual category of acceptability: relatively acceptable, barely acceptable, unacceptable, 
absolutely unacceptable, etc. (Berezovskaya \& Demchenkov 2016: 64-67). Typical elements of this genre are catastrophe, the decline of civilization (on technological and sociocultural levels), pandemic (virus, mutations etc.), "usthem" opposition, and political crisis (Chesnova et al. 2017: 46).

Since the world-modelling takes place in two layers: the description of the pre-apocalyptic living and non-living objects adapting to new conditions, and the development of a post-nuclear war world, pragmatonyms apply to both a pre-war and a post-war world.

In addition, pre-war and post-war pragmatonyms refer to the real world and therefore are a part of players' background knowledge about the world; the game is perceived as a possible world model. These names are semantically unmotivated: Beer, Bubble gum, Fruit etc. Furthermore, pragmatonyms refer to the game model of the world: names are semantically motivated and are important for developing game worldview in accordance with given genre specifics.

As it can be seen in Table 2, all product names are divided into two big groups, the products made before and after the war. Products manufactured before the war include connotative names, aimed at encouraging the potential clients to buy goods (Dandy Boy Apples, Fancy Lads Snack Cakes, Sunset Sarsaparilla), names indicating the company (Blamco Brand Mac and Cheese, BlamCo Mac \& Cheese, Nuka-Cherry), common names of items (to give information about all the things referred to by a noun: Scotch, Wine, Vodka, Whiskey), and names creating allusions to existing products used during the war $\left(\mathrm{Cram}-\mathrm{Spam}^{3}\right)$. In the products made after the war, the most frequent naming pattern is the "attribute + object" pattern, where the attribute's meaning is the name of the animal the product is made of (Mole rat chunks, Radstag meat, Stingwing filet), or product quality (Dirty Water, Fresh carrot, Fresh melon).

Table 2: The quantitative proportionality of Fallout New Vegas and Fallout 4 pragmatonyms concerning composition and semantical motivation or the absence of the latter.

\begin{tabular}{|r|c|c|c|c|c|}
\hline & & \multicolumn{2}{|c|}{ Pre-war pragmatonyms } & \multicolumn{2}{c|}{ Post-war pragmatonyms } \\
\hline & $\begin{array}{c}\text { Onyms } \\
\text { total }\end{array}$ & $\begin{array}{c}\text { correlate } \\
\text { with the } \\
\text { real world }\end{array}$ & $\begin{array}{c}\text { refer to the } \\
\text { game world } \\
\text { model }\end{array}$ & $\begin{array}{c}\text { correlate } \\
\text { with the } \\
\text { real world }\end{array}$ & $\begin{array}{c}\text { refer to the } \\
\text { game world } \\
\text { model }\end{array}$ \\
\hline $\begin{array}{r}\text { 1 word } \\
\text { pragmatonyms }\end{array}$ & 82 & 9 & 39 & 8 & 26 \\
\hline $\begin{array}{r}2 \text { words } \\
\text { pragmatonyms }\end{array}$ & 204 & 3 & 36 & 4 & 161 \\
\hline $\begin{array}{r}3 \text { or more words } \\
\text { pragmatonyms }\end{array}$ & 138 & 1 & 61 & 8 & 68 \\
\hline
\end{tabular}

Thus, the pragmatonyms take part in a post-apocalyptic worldview formation depicting the technologically and culturally advanced pre-war world

3 Spam or SPAM is a brand of canned meat in the USA that gained popularity during World War II. 
with the developed food and processing industry (Blamco Brand Mac and Cheese, Nuka-Cola) and the adapting post-war world. The latter is shown with already existing objects changing, usually with the help of the meaning 'radiation or radioactive contamination' (Irradiated water, Rad-rat, Radroach, Radstag), and with new objects appearing (Nightstalker tail, Yao guai meat).

\subsection{What is the role of pragmatonyms in the game worldview formation in terms of game interactivity referring to the game as a media text?}

Regarding the computer game as a media text, it is worth noting that interactivity is its key feature distinguishing a media text from other texts. As the game itself consists of a number of elements, both linguistic and extralinguistic, it is given that all these objects have their names and, consequently, must be named in such patterns that ensure the player-game interaction. It is hypothesized that the pragmatonyms have definite word meanings used as motivations that are aimed at provoking a definite reaction. To prove so, the componential and cognitive analyses were implemented.

As to the semantic motivation of pragmatonyms as means of game worldview formation and player-game interaction ensuring, the main word meanings used as bases of formation of pragmatonyms have been analysed. While each group (pragmatonyms of one, two, or three or more words) has been studied separately, it seems justified to make a review of obtained data to see what meanings are key elements of world modelling in a given genre.

Tables 3 and 4 list the most common word meanings of pragmatonyms. It should be specifically noted that one onym can have more than one word meaning serving as a basis of objects' naming. Studies show that the quantity of word meanings usually varies from one to two meanings. As the postapocalyptic world-modelling presupposes the contrast of the world before and after the disaster, the word meanings are presented accordingly.

Table 3: Classification of pre-war pragmatonyms

\begin{tabular}{|l|c|l|}
\hline Principle of naming & Count & Examples \\
\hline Product quality & 65 & Ice cold Gwinnett ale, Preserved meat \\
\hline Manufacturer or seller & 50 & BlamCo Mac \& Cheese, Ice cold Nuka-Cola \\
\hline $\begin{array}{l}\text { Radiation, radioactive } \\
\text { contamination }\end{array}$ & 42 & Irradiated Sunset Sarsaparilla, Nuka-Xtreme \\
\hline Product impact & 24 & Day Tripper, Fixer, Steady \\
\hline Product appearance & 14 & Cotton candy bites, Cram, Food paste \\
\hline Working principle & 3 & InstaMash, Jet, Stealth Boy \\
\hline
\end{tabular}


Table 4: Classification of post-war pragmatonyms

\begin{tabular}{|l|c|l|}
\hline Principle of naming & Count & Examples \\
\hline Dish or method of preparation & 62 & Deathclaw steak, Fire ant fricassee \\
\hline $\begin{array}{l}\text { Animal from which the } \\
\text { product is made }\end{array}$ & 61 & Bighorner meat, Cave cricket meat \\
\hline Product quality & 49 & Crispy squirrel bits, Crunchy mutfruit, Ultrajet \\
\hline Product impact & 47 & $\begin{array}{l}\text { Auto-inject super stimpak, Herbal } \\
\text { antimicrobial, Hydra }\end{array}$ \\
\hline Product appearance & 31 & Happy Birthday sweet roll, Potted meat \\
\hline $\begin{array}{l}\text { Radiation, radioactive } \\
\text { contamination }\end{array}$ & 30 & $\begin{array}{l}\text { Irradiated crunchy mutfruit, Mushroom Cloud, } \\
\text { Mutfruit }\end{array}$ \\
\hline Location & 11 & Cave fungus, Institute food packet \\
\hline $\begin{array}{l}\text { Plant from which the } \\
\text { product is obtained }\end{array}$ & 7 & Carrot flower, Spore plant pods \\
\hline Manufacturer or seller & 7 & Cook-Cook's Fiend stew, Deezer's Lemonade \\
\hline Ingredients & 4 & Herbal antimicrobial, Silver Sting \\
\hline Working principle & 2 & Auto-inject stimpak, Auto-inject super stimpak \\
\hline Modernity & 1 & Newka-Cola \\
\hline
\end{tabular}

It seems logical to start with the investigation of the pre-war-post-war opposition as a genre-defining element of post-apocalyptic fiction. The meanings 'product quality' and 'manufacturer or seller' serve to create an advanced civilization worldview. In contrast, the meanings 'radiation or radioactive contamination', 'animal from which the product is made', 'plant from which the product is obtained', 'ingredients' depict the world suffering from the nuclear holocaust, reverting to its primitive hunter-gatherer state with most foods obtained by foraging.

As to Fallout: New Vegas and Fallout 4 being RPGs, the most frequent word meanings serving as bases of naming are 'product quality', 'product impact', and 'animal from which the product is made'. This fact meets the interactivity feature of a computer game and is aimed at the player adopting the best strategy under current circumstances. For example, if the Health of a character is too low for the combat, they might consider taking a more valuable but necessary in such situation Purified water ( +40 Hit Points) instead of Dirty water ( +20 Hit Points, +7 Radiation in Fallout 4). If the Health is critically low, based on the "product impact", the player may make their choice in favour of Stimpak ( +30 Hit Points in Fallout: New Vegas) or Super stimpak (+60 Hit Points in Fallout: New Vegas), being mindful of the negative effect of the latter - the Super stimpak sickness $(-1$ Strength, -1 Agility).

Other commonly occurring meanings are 'radiation or radioactive contamination', 'dish or cooking method' which are a consequence of the introduction of activated game objects: Campfire, Electric hot plate, Cooking station, and Cooking stove. Since cooked food may be cleared of radiation, it 
may significantly increase the health points and produce a certain effect aimed at increasing and (or) lowering the primary and derived statistics of the player character, the pragmatonyms naming these products should be easily allocated by the player.

As demonstrated in Table 5, the pragmatonyms with the meaning 'dish or cooking method' as a basis of naming, surpass those with the meaning 'animal from which the product is made' in influencing the player character positively. As a result, to show the superiority of such consumables over Wasteland-found ones and their specifics of the impact, pragmatonyms meaning 'dish or cooking process' have the following lexical units in their word composition: They may express dish (cake, chops, chunks, fricassee, jerky, kebab, omelet, pie, ribs, salad, sauce, slider, slurry, soup, steak, stew, Wellington) and are named according to the "animal + dish" pattern and less often "manufacturer + dish" pattern as well as "location + dish" pattern: (Mirelurk cake, Cook-Cook's Fiend stew, Wasteland omelette). They may also express cooking method (baked, fried, grilled, poached, roasted) and are named according to the 'cooking method + animal' pattern (Grilled radroach).

Table 5: An example of a name of consumable with the meaning 'animal from which the product is made' as a basis of naming in comparison with a name of consumable with the central meaning 'dish or cooking method', showing differences in effect producing.

\begin{tabular}{|l|l|l|l|l|}
\hline Pragmatonym & $\begin{array}{l}\text { Central meaning/ } \\
\text { motivation }\end{array}$ & $\begin{array}{l}\text { Health } \\
\text { Attribute } \\
\text { Increase by }\end{array}$ & $\begin{array}{l}\text { Radiation } \\
\text { Poisoning } \\
\text { by }\end{array}$ & $\begin{array}{l}\text { Additional } \\
\text { Effects }\end{array}$ \\
\hline $\begin{array}{l}\text { Radscorpion egg } \\
\text { (Fallout 4) }\end{array}$ & $\begin{array}{l}\text { 'animal from which } \\
\text { the product is made' }\end{array}$ & $\begin{array}{l}+35 \mathrm{Hit} \\
\text { Points }\end{array}$ & $\begin{array}{l}+11 \\
\text { Radiation }\end{array}$ & - \\
\hline $\begin{array}{l}\text { Radscorpion egg } \\
\text { omelette (Fallout 4) }\end{array}$ & $\begin{array}{l}\text { 'dish/cooking } \\
\text { method' }\end{array}$ & $\begin{array}{l}+75 \mathrm{Hit} \\
\text { Points }\end{array}$ & - & $\begin{array}{l}\text { Cures } \\
\text { addictions }\end{array}$ \\
\hline $\begin{array}{l}\text { Rad-rat meat (Fallout 4; } \\
\text { add-on: Nuka-World) }\end{array}$ & $\begin{array}{l}\text { 'animal from which } \\
\text { the product is made' }\end{array}$ & $\begin{array}{l}+25 \mathrm{Hit} \\
\text { Points }\end{array}$ & $\begin{array}{l}+5 \\
\text { Radiation }\end{array}$ & - \\
\hline $\begin{array}{l}\text { Rad-rat steak (Fallout 4; } \\
\text { add-on: Nuka-World) }\end{array}$ & $\begin{array}{l}\text { 'dish/cooking } \\
\text { method' }\end{array}$ & $\begin{array}{l}+48 \mathrm{Hit} \\
\text { Points }\end{array}$ & - & $\begin{array}{l}+5 \text { Action } \\
\text { Points }\end{array}$ \\
\hline
\end{tabular}

The frequent word meaning 'manufacturer or seller' produces a similar impact on the player as the meaning 'location' does. The pragmatonyms with the meaning 'manufacturer or seller' primarily indicate the location where the product can be found: Bobrov's Best moonshine, Ware's Brew, Ice cold Nuka-Cherry etc.

The meaning 'radiation or radioactive contamination', on the one hand, is used to create the setting of the game, the post-nuclear war world. On the other hand, it contributes to the category of acceptability display as the characteristic feature of a post-apocalyptic genre. The same objective is achieved by the pragmatonyms that have the meaning 'product quality'.

4 Action points are used in the V.A.T.S. system (queuing combat system) to attack opponents. 
As for the gradation of the category of acceptability, in Fallout, it is as follows: good, acceptable, relatively acceptable, barely acceptable, unacceptable. One of the most common products, Water, and its variants most fully reflect the gradation of the category: Cactus water-Purified water-Dirty water-Drugged water-Irradiated water. The category of acceptability is also expressed by oppositions, such as "good-acceptable" (Fresh carrot - Carrot, Glowing blood pack-Blood pack, Super stimpak - Stimpak), "good-barely acceptable or unacceptable" (Crunchy mutfruit - Irradiated mutfruit), "acceptable-barely acceptable or unacceptable" (Brahmin meat - Infected brahmin meat, Potato Crisps - Irradiated Potato Crisps) (Kuzmenko 2018b: 196).

The acceptability is expressed by pragmatonyms with a neutral connotation, the good quality is expressed in the first part of the naming pattern "attribute + object" using the word with a positive connotation: crunchy, fresh, super, ultra. Similarly, the category of unacceptability or low acceptability is expressed by words with a negative connotation: dirty, infected, irradiated. The category of acceptability, being a post-apocalyptic genre characteristic, is essential for the player in adopting a strategy. Based on their current statistics, the player can choose what product they must consume to accomplish the mission. For example, if the player character suffers from radiation poisoning, they might choose a fresh product instead of an irradiated one.

Thus, the pragmatonyms play an important role in objects' preliminary identification by the player and in the player adopting a definite strategy based on their current statistics. The essential meanings 'product quality', 'product impact', 'animal from which the product is made', and 'dish or cooking method' are aimed at being quickly perceived by the players, for example in case of a player being in combat, and are named accordingly to give a clear understanding of the effect they produce on the player.

\section{Conclusion}

A pragmatonym in Fallout is a name of any consumable. Since the game world model comprises a number of objects, their names in combination with the media objects of extralinguistic reality play a vital role in the player's inclusion into the narration. The importance of pragmatonyms correlate with the impact of consumables on the player character in RPG - nearly all the consumables affect the player character in one or another way.

The role of pragmatonyms is consistent with the post-apocalyptic genreforming features, namely the world being divided into two layers - pre-war and post-war. Pragmatonyms take part in the formation of these two worldviews. Semantically unmotivated pre-war pragmatonyms correlate with the player's background knowledge of the existing world that makes them believe in the reality model of the game. Semantically motivated pre-war pragmatonyms, in turn, are used to form a new worldview - the retro-futuristic 
world. Post-war pragmatonyms are not only means of involving the player in a changing post-apocalyptic world setting by showing pre-war objects adapting, but they also play a role in a player employing a strategy, depending on the current characteristics of the player character.

The same applies to the category of acceptability. On the one hand, pragmatonyms expressing the acceptability category serve as a genre-defining feature of the post-apocalyptic fiction. On the other hand, they are also important for the player in adopting a strategy in terms of the game as a media text of the RPG genre. In Fallout, the acceptability category ranges between "good", expressed with words with a positive connotation (Fresh, Super) and "barely acceptable or unacceptable", shown by words with a negative connotation and additional meaning of caution (Infected, Irradiated).

Thus, the interactivity of a computer game as a media text represents the interaction of the player and the game and is characterized by the intermutual process: the game producing the impact on the player as well as the player influencing the game. The game is based on a number of non-linguistic and linguistic objects that ensure the interactivity. Pragmatonyms play an important role in the preliminary identification of objects by helping to understand their working principle and impact.

Based on the central meanings of objects' names, the player evaluates the effectiveness of their strategy, choosing whether they should interact with objects, non-player characters, locations, etc. Therefore, the player develops their character and also affects the game, changing its plot in given frames.

Taking into account the aforementioned criteria, it is unequivocal that pragmatonyms not only play an important role in players' involvement into the game world and its setting but are also essential in terms of interaction with the objects.

\section{References}

Berezovskaya, L. S. \& Demchenkov, S. A. 2016. Postapokaliptika kak zhanr nauchnoj/paranauchnoj fantastiki [Post-apocalyptic as a scientific/ parascientific genre]. Gumanitarnye issledovanija 4(13), 64-67.

Bethesda Softworks. 2015. Fallout 4. Microsoft Windows, PlayStation 3, Xbox 360. (https://bethesda.net/en/article/6BgcINFtZYSq4YGYaQkIWm/ fallout-4-player-freedom-in-an-open-world) (Accessed 2019-07-07.)

Bissell, Tom. 2010. Extra lives: Why video games matter. New York: Pantheon Books. (https://archive.org/details/extraliveswhyvid00biss/page/218) (Accessed 2019-07-07.)

Burlakov, Igor' V. 2000. Homo Gamer: Psihologija komp'juternyh igr [Homo Gamer: Psychology of computer games]. Moscow: Nezavisimaja firma 
'Klass'. (https://www.gumer.info/bibliotek_Buks/Psihol/Article/burl_ homgam.php) (Accessed 2020-05-13.)

Butler, James. 2016. New digital worlds to explore: The onomastic styling of procedural and open-world videogames. In Hough, Carole \& Izdebska, Daria (eds.), Names and their environment. Proceedings of the 25th International Congress of Onomastic Sciences, Glasgow, 25-29 August 2014, vol. 5, 22-28. (https://www.gla.ac.uk/media/Media_576599 smxx.pdf) (Accessed 2020-03-09.)

Chesnova, Yelena. N. \& Mansurova, Shamella I. \& Snytina, Anastasiya A. 2017. Filosofiya mirov postapokalipsisa v sovremennoy kul'ture [The philosophy of worlds of post-apocalypse in modern culture]. Gumanitarnyye vedomosti TSPUT im. L. N. Tolstogo 2(22), 46-54.

Cooper, Kendra M. L. \& Scacchi, Walt. 2015. Computer games and software engineering. New York: Chapman and Hall/CRC.

Dydrov, Artur A. 2015. Terra utopia: khrebty i plato [Terra utopia: Ridges and plateaus]. Bulletin of the South Ural State University Series "Humanities and social sciences" 15(1), 110-112.

Galkin, Dmitriy V. 2007. Komp'juternye igry kak fenomen sovremennoj kul'tury: opyt mezhdisciplinarnogo issledovanija [Computer games as phenomenon of modern culture: An interdisciplinary study]. Gumanitarnaja informatika 3, 54-72.

Goroshko, Olena I. 2015. Lingvistika novyh medij kak odin iz vyzovov lingvisticheskoj tradicii proshlogo [Linguistics of new media as a challenge to traditional linguistics of the past]. Voprosy psiholingvistiki $24,43-54$.

Hämäläinen, Lasse. 2019a. Level names in an online minigolf game. Onomastica Uralica 10, 317-329. (http://mnytud.arts.unideb.hu/ onomural/kotetek/ou10/23.pdf) (Accessed 2020-03-09.)

Hämäläinen, Lasse. 2019b. User names of illegal drug vendors on a darknet cryptomarket. Onoma 50, 43-68. (https://onomajournal.org/wp-content/ uploads/2019/04/Onoma_50_Hamalainen.pdf) (Accessed 2019-07-20.)

HiddenX. 2014. The CRPG Analyzer: A checklist for computer roleplaying games. RPGWatch.com. (https://www.rpgwatch.com/forums/showpost. php? $\mathrm{p}=1061254692$ \&postcount=367) $($ Accessed 2019-07-16.)

ICOS. (n.d.). List of Key Onomastic Terms. ICOS Terminology Group. (https://icosweb.net/wp/wp-content/uploads/2019/05/ICOS-Terms-en.pdf) (Accessed 2020-04-01.)

Ivanova, Yelena V. 2013. Ekologicheskaya problematika v fantasticheskom diskurse [Environmental problems in fiction discourse]. Vestnik Chelyabinskogo gosudarstvennogo universiteta 37(328), 145-147. (Filologiya. Iskusstvovedeniye 86.) 
Jakobson, Roman O. 1975. Lingvistika i poetika [Linguistics and poetics]. Strukturalizm: 'za' $i$ 'protiv', 193-230. (http://plr.iling-ran.ru/ru/node/34) (Accessed 2019-07-07.)

Kazakova, Irina A. 2011. Istoriya vychislitelnoj tekhniki [History of computing technics: Study guide]. Penza: PGU Publishing.

Krasnoyarova, Ol'ga V. 2010. Mediynyy tekst: yego osobennosti i vidy [Media text: Its characteristics and types]. Izvestiya Baykal'skogo gosudarstvennogo universiteta 3(71), 177-181.

Krasnoyarova, Ol'ga V. 2015. Tekst i mediatekst: problema differentsiatsii ponyatij [Text and media text: The problem of differentiation of concepts]. Voprosy teorii i praktiki zhurnalistiki 4(1), 85-100.

Kuz'mina, Natalya A. 2011. Sovremennyy mediatekst: uchebnoye posobiye [Modern media text: Study guide]. Omsk: Tatyana Printing Center.

Kuzmenko, Aleksandra, N. 2018a. Rol' pragmatonimov v formirovanii yazykovoy kartiny mira $\mathrm{v}$ komp'yuternykh igrakh (na materiale komp'yuternykh igr serii Fallout) [The role of pragmatonyms in the formation of the linguistic worldview in computer games (based on the Fallout video game series)]. Gumanitarno-pedagogicheskoye obrazovaniye 4(4), 69-75.

Kuzmenko, Aleksandra, N. 2018b. Yazykovyye sredstva vyrazheniya kategorii priyemlemosti v proizvedeniyakh zhanra postapokaliptika (na materiale serii komp'yuternykh igr Fallout) [Linguistic means of the acceptability category expression of post-apocalyptic fiction (based on the Fallout video game series)]. In Materials of interdisciplinary scientific and practical forum of philologists, 195-198.

Maksimenko, Ol'ga I. 2011. Semioticheskie osobennosti mediateksta interneta [Semiotic characteristics of the internet media texts]. Vestnik RUDN. Language Theory. Semiotics. Semantics 1, 50-58.

Martin, Paul. 2011. Toponymy in the videogame Grand Theft Auto IV. Onoma 46, 5-26. (https://www.academia.edu/925356/Toponymy_in_the videogame_Grand_Theft_Auto_IV) (Accessed 2020-03-09.)

Nukapedia. (n.d.) The Fallout Wiki. (https://fallout.fandom.com/wiki/Fallout_Wiki) (Accessed 2020-03-31.)

Obsidian Entertainment. 2010. Fallout: New Vegas. Microsoft Windows, PlayStation 3, Xbox 360. (https://www.obsidian.net/games\#fnv) (Accessed 2020-04-04.)

Podol'skaya, Natalya V. 1978. Slovar' russkoj onomasticheskoj terminologii [Dictionary of Russian onomastics]. Moscow: Nauka Publ.

Protalinski, Emil. 2011. The US legally recognizes video games as an art form. Techspot. (https://www.techspot.com/news/43696-the-us-legallyrecognizes-video-games-as-an-art-form.html) (Accessed 2019-07-16.) 
Psmit, Richard. 2006. Kak dat' geroyu imya [How to name a character]. Luchshiye komp'yuternyye igry 5(54). (http://www.lki.ru/text.php? $\mathrm{id}=1105)$ (Accessed 2019-07-11.)

Rogers, Scott. 2010. Level up! The guide to great video game design. Chichester: John Wiley \& Sons.

Rollings, Andrew \& Morris, Dave. 2006. Proektirovanie i arhitektura igr [Game architecture and design]. Moscow: "Vilyams" Publishing House. (Translated from English by A.A. Chekatkova.)

Saussure, Ferdinand de. 1977. Trydy po yazyloznaniyu [Works on linguistics: Course in general linguistics]. Moscow: Progress Publishing Group.

Shaker, Noor \& Togelius, Julian \& Nelson, Mark J. 2016. Procedural content generation in games. Cham: Springer.

Shherbak, Antonina S. 2012. Kognitivnye osnovy regional'noj onomastiki [Cognitive foundations of regional onomastics]. Tambov: Izdatel'skij dom TGU im. G.R. Derzhavina.

Spector, Warren. 2013. Who forgot the "role" in Role-Playing Games? Gamasutra. (https://www.gamasutra.com/view/news/197021/Warren_Spector_Who forgot the_role_in_RolePlaying_Games.php) (Accessed 2019-07-07.)

Volkova, Irina I. 2017. Komp'yuternyye igry i novyye media: igrovoy podkhod $\mathrm{k}$ kommunikatsiyam $\mathrm{v}$ virtual'nom prostranstve [Video games and new media: Game approach to communications within virtual space]. RUDN Journal of Studies in Literature and Journalism 22(2), 312-320.

Yakovlev, Andrey A. 2017. Yazykovaya kartina mira kak lingvisticheskoye ponyatiye: obzor rossiyskikh publikatsiy poslednikh let [Linguistic worldview as a linguistic notion: Review of recent Russian works]. Vestnik Novosibirskogo gosudarstvennogo universiteta. Seriya: Lingvistika $i$ mezhkul'turnaya kommunikatsiya 15(2), 5-20. 